\title{
Application Design Resume Medical By Using Microsoft Visual Basic.Net 2010 At The Health Center Appointments
}

\author{
Samsir $^{1 *}$, Syaiful Zuhri Harahap ${ }^{2}$ \\ ${ }^{*}$ Faculty Of Engineering, Universitas Al-Washliyah Labuhanbatu \\ Sumatera Utara, Indonesia. \\ ${ }^{2}$ Faculty Of Science \& Technology, Universitas Labuhanbatu \\ Sumatera Utara, Indonesia. \\ ${ }^{*}$ Corresponding author: \\ Email: samsirst111@gmail.com
}

\begin{abstract}
.
In implementing health services, puskesmas must document all actions and treatments that are given to patients in a document called Medical Records. According to Minister of Health Regulation No.269 / MENKES / PER / III / 2008 article 1 (1), medical records are files containing notes and documents about patient identities. Medical records are of good quality if the medical record is accurate, complete, trustworthy, valid and timely. One form of management in Medical Records is reporting. According to Minister of Health Regulation No.269 / MENKES / PER / III / 2008 article 1 (1), Medical Record is a file that contains notes and documents about patient identity, examinations, actions, and other services that have been given to patients. In the statement, all information about a patient has been reflected which will be made the basis for determining further actions in services and other medical actions given to a patient who comes to the community health center. The Medical Record is said to be of high quality if the Medical Record is accurate, complete, trustworthy, valid and timely. The Medical Record Installation has activities such as registration, data processing, and storage. One form of processing data in medical records is the existence of assembling activities. Assembling is an assembling activity compiling empty Medical Record forms and storing them into Medical Records, ready to use neatly arranged both in terms of quality and quality.
\end{abstract}

Keyword: Designing, Medical, Microsoft Visual Basic.Net 2010

\section{INTRODUCTION}

Design is the main proposals that change something that already exists into something better, through three processes : identify problems, identify methods for solving problems and implementation of problem-solving. Peracncangan is drawing, planning and making sketches or arrangement of several separate elements into a unified whole and the functioning [1]. Design is the process of developing new specifications based on the recommendations the results of the analysis of the system [2]. Information systems medical records patient outpatient is an information system that aims to manage the data of patients who seek treatment to such patients out of the hospital or clinic in a certain period.

The information system designed is very important to prevent the occurrence of errors procedures in the implementation of registration and data management. Information 
system in a health clinic this is an information system that contains patient data, drug data, transaction data and the patient medical record. As for the previous performance of the system in the service of the patients that walk in health clinics in general is not optimal because it is still in the processing of patient data and medical records still use the media bookkeeping or manual. The management of patient data in the Clinic Healthy Margasari is still not effective because the system used ? less complete so that the patient service to be slow and patient record is often missing or not found. Then patient services to be not effective and efficient, because the manual system of bookkeeping slows down the making of a report or search data of the patient. Patient care information system designed aimed to build a computerized information system, thus making the health clinics processing patient data, drug, transaction, medical record, medical action patient until the printing of the report.

Phc Promise of one form of health-care facilities to the community held by the government is the health center. Health care facilities this is central to the development of public health in fostering community participation also provides comprehensive services and integrated to the community. In other words, the health center has the authority and responsibility for the maintenance of public health in the region it works. The health service addressed to all the population, does not differentiate gender and age group, since conception in the womb up to the cap age. Health center Appointments the district labuhanbatu.The position of the health center is very strategic close to the capital city of the district, namely kabupaten labuhanbatu so if there are patients that can not afford treated at the puskesmas then quickly can send to the district general hospital that is full of the means to the equipment. Phc promise of trying to be health centers are the best in the district labuhanbatu so that it can be an example with puskesmas puskesmas in the District labuhanbatu and also trying in order to become the health center the best in lutein

\section{EXPERIMENTAL}

\section{Understanding Of Information Systems}

The information system designed is very important to prevent the occurrence of errors procedures in the implementation of registration and data management. Information system in a health clinic this is an information system that contains patient data, drug data, transaction data and the patient medical record. As for the previous performance of the system in the service of the patients that walk in health clinics in general is not optimal because it is still in the processing of patient data and medical records still use the media bookkeeping or manual. The management of patient data in the Clinic Healthy Margasari is still not effective because the system used ? less complete so that the patient service to be slow and patient record is often missing or not found. Then patient services to be not effective and efficient, because the manual system of bookkeeping slows down the making of a report or search data of the patient. Patient care information system designed aimed to build a computerized information system, thus making the health clinics processing patient data, drug, transaction, medical record, medical action patient until the printing of the report.

In terms of understanding the application is a program that is ready to use created to implement a function for the user application services and the use of other applications that can be used by a target that will be addressed. According to the 
dictionary of computer executive, an have a sense of problem-solving using one of the techniques of data processing applications that usually raced on a komputansi desired or expected and processing the data that is expected. Understanding the application according to Big Indonesian Dictionary, "the App is the application of design systems to process data using rules or the terms of a particular programming language".

is the use of a computer, the instructions (instruction) or a statement (statement) which are arranged in such a way so that the computer can process the input into output [3]. The application of design systems to process data using rules or the terms of a particular programming language. The application is a computer program created to perform and carry out special tasks of the user. According to Rachmad Hakim S, is software used for a specific purpose, such as processing documents, arranging Windows \& game, (game), and so on. According to the Harip Santoso, is a group of files (form, class, rePort) that aims to perform a certain activity are interrelated, for example, application payroll, the application of fixed assets.

System as an entity consisting of two or more components or subsystems that interact to affirm a goal [4]. System is a collection of elements that interact to achieve a certain goal [5]. There are two groups of approaches in defining the system, namely the emphasis on the procedure and the emphasize on the components or elements. A system is a network to perform an activity or to accomplish a particular goal. While the notion of procedure itself, according to Richard F. Neuschel, the procedure of a sequence - clerical operations (writing), usually involves several people within one or more departments, which is applied to ensure uniform handling of the business transactions that occur [6].

2. Understanding The Information

Information is data processed into a form that is more useful and more meaningful for those who receive it. Information as a result of processing the data in a form that is more useful and more meaningful for the recipient that illustrates real events that are used for decision making [7]. Information is data shaped into a form that is more useful and more meaningful for the recipient [8]. that information is data that provides useful knowledge. Meanwhile, according to Gordon B. Davis information is a data that is processed into a form that is important bafi receiver and has real value or that can be perceived in the decisions that are now or that will come [9]. Information System is a system within an organization that meets the daily transaction processing needs, support operations, managerial activities and strategic of an organization and provide certain outside parties with the necessary reports [10]. The Information system is a system in an organization that is a combination of people, facilities, technology, media, procedures and controls [11].

\section{$3 . \quad$ Understanding The Data}

Data is the thing which refers to facts either in the form of numbers, text, documents, images, charts, sound representing the descriptive verbal or specific code and such. So data is the raw form that need to be further processed [12].

4. Understanding Of The Medical Record

The medical record is information in both written and recorded about the identity, anamnesis, determination of physical, laboratory, diagnosis and medical acts provided to the patient and treatment of both hospitalized, outpatient care or to get emergency services. If interpreted in simple terms, medical records seemed to be just a 
record and a document about the state of the patient, but if studied more in the medical record has a broader meaning than in regular notes, having reflected all information concerning a patient that will be used as the basis in determining further action in the effort of service and other medical procedures are given to a person the patient came to the hospital. File medical records a hospital should not be sent to a nursing other if the patient is referred to get follow-up care in an institution or another hospital, which sent quite the resume (conclusions) only. Negligence in the management and use of the medical record may be subject to sanctions by the Director general of Yanmed or the Director of the Hospital concerned.(Book of Guidance Note Medical series 7 the revisions made based on Permenkes No. 749 a / Menkes / Per / XII / 1998).

5. Resume Medical

In The who referred to the medical resume is a summary of the services provided by most health care provider or doctor, during the treatment period until the patient out of the hospital alive or died.According to the Guidelines for the Management of the Hospital Medical [13]. a summary can be written at the end of the progress notes or with a sheet of its own. For the hospital-a small hospital it is determined by the usefulness of such records. The exception for resume medical this especially for the patients treated in less than 48 hours. The clinic is a unitary functional organization that organizes the efforts of health care that is comprehensive, integrated, evenly acceptable and affordable by the community with the active participation of the community and use the results of the development of science and appropriate technology, with costs that can be borne by the government and the wider community in order to achieve the optimal degree of health, without ignoring the quality of service on the individual [14].

\section{METHODS}

In this design stage, the authors will design how to Design Reume Medical that will built can run well in the stage of implementation, the first design that will be made, namely the workflow system Application Resume Medical and or create a design modeling flowchart the system, then will make the design of the display interface or the appearance of the user interface and the user. Design is is the stage after the analysis of the cycle pengembanemanem : Definition of needs and per second before batula up implementation:" Mengembarkan how suuklesl". The design can be melakukanefinisikan as haggambaran, planning and emulsifiers Darman dariapa desberman El separate into sateatuan satesatuan uquatuan uuhfungsi [15].

\section{RESULT AND DISCUSSION}

\section{a.The Login Page}

On the login page of the application resume medical health center Appointments her look like the picture below,on this page there is a form the username and password and login button,delete and cancel, Then if you want to get into the system application resum medical at the health center appointments kecamayan the bar of the western district labuhanbatu have to go through the first login so the system in the application resum medical can be maintained with a safe and secure and can't be bothered by people who are not interested in it. 


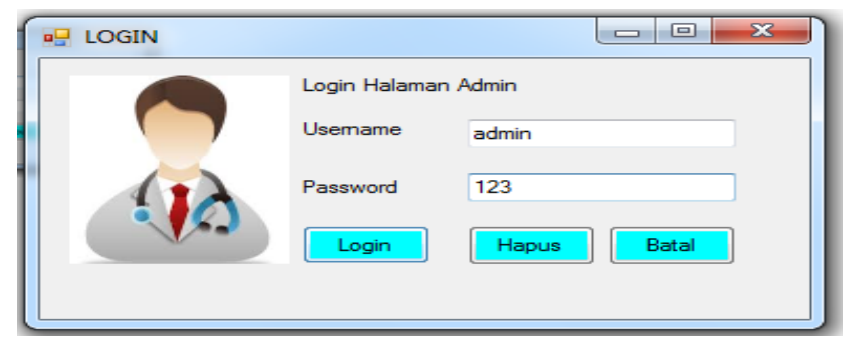

Fig 1. The Appearance Of The Page

b. The Main Menu Page

The main menu page on the app resumes medical looks like the picture below. On the main menu page there are several menu that is menu data input resumes, the reports menu resume medical and exit the menu.

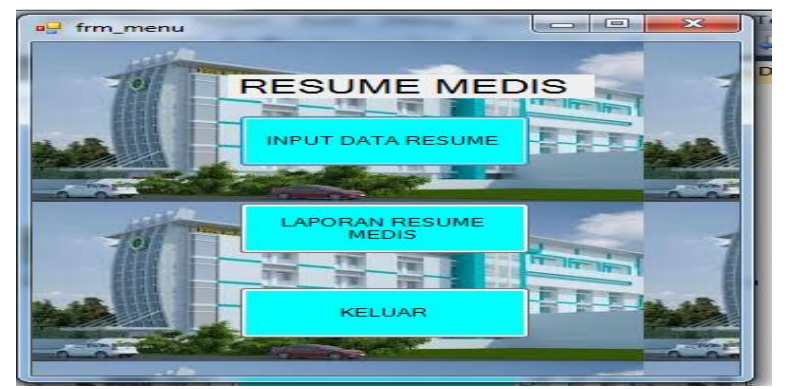

Figure 2. The appearance of the main page

c. Page Input A Resume Medical

Page data input resume medical looks on the picture as below.On the display page the input resumes medical there are several forms of charging data for the patient that will be taking resumes medical and there are several buttons, namely buttons save,edit,delete and back then there is a form to search data of patients resume a medical.

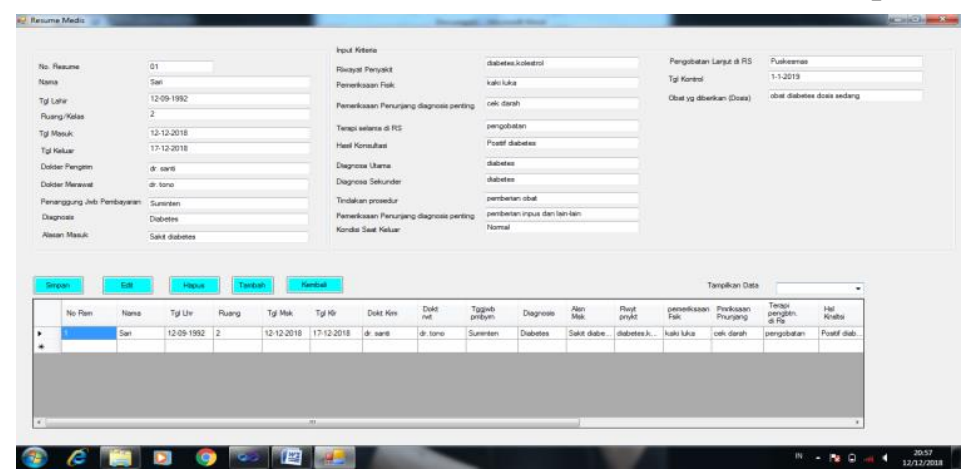

Fig 3. Page Input Resume Medical

d. Report Page Resumes Medical

Report page resumes medical how it looks can be seen like the picture below.On the view reports page of resume medical these are the overall data of patients who did resume medical,admin can also view the report data resume medical someone who's never done a resume medical health center Appointment only by filling out the form find data with input No resume medical and then press find data. 


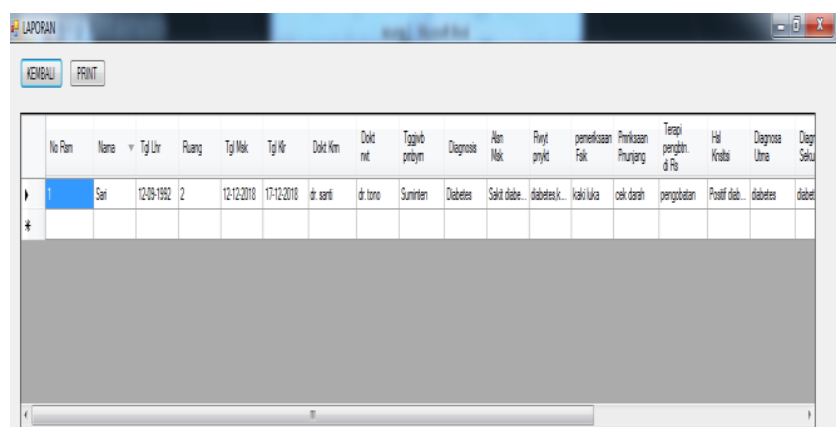

Fig 4. Display The Reports Page Of Resume Medical

e. The Appearance Of The Output

Display this output contains the data central resume medical overall, the picture of his look can be seen below.

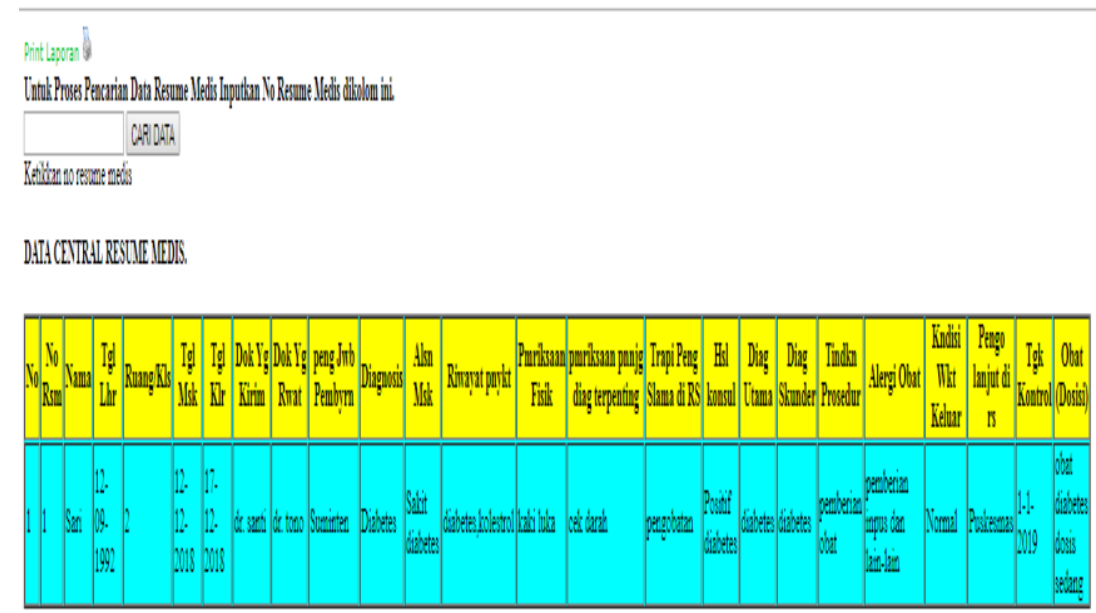

Fig 6. The Appearance Of The Output

\section{CONCLUSION}

The conclusion that can be drawn from the research to making the application Resume Medical this is that this application is only processing services Resume Medical health center Appointments and not for the service of others.and this app can answer the problems that occur in the health center promises that it can fix the system manually into the computerized system, the existing data dipuskesmas the promise of safer,more recorded and more accurate so that the system application resum medical appointment could answer all the problems that occur in particular resum medical.

\section{REFERENCNE}

[1] Amitab, M., Navnish, G., Tarun, K., Sachin, G., and Rohit Rana., (2014).“Data Mining Techique With Crossbreeding Neural Network : LVQ and Hopfield" Scholedge 
International Journal Of Multidisciplinary \& Allied Studies. Vol. 1, Issue 2 (November 2014). ISSN-2394-336X

[2] Angga Setiawan., Achmad Hidayatno., dan R. Rizal Isnanto., (2011). “Aplikasi Pengenalan Ucapan Dengan Ekstraksi Mel-Frequency Cepstrum Coefecients (MFCC) Melalui Jaringan Syaraf Tiruan (JST) Learning Vector Quantization (LVQ) untuk Mengoperasikan Kursor Komputer ." Available online at TRANSMISI Website http://ejournal.undip.ac.id/index.php/transmisi TRANSMISI, 13 (3), 2011, 82-86.

[3] B.Alijla., and K.Kwaik., (2012).”OIAHCR : Online Isolated Arabic Handwritten Character Recognition Using Neural Network" The International Arab Journal of Information Technology, Vol. 9, No. 4, July 2012.

[4] D.Bhattacharyya., and Tai-hoon Kim., (2010).“Design of Artificial Neural Network for Handwritten Signature Recognition." International Journal Of Computer and Communications. Issue 3, Volume 4, 2010.

[5] Qur'aini., dan Rosmalinda., (2010).’Jaringan Syaraf Tiruan Learning Vector Quantization untuk Aplikasi Pengenal Tanda Tangan" Seminar Nasional Aplikasi Teknologi Informasi 2010 (SNATI 2010). Yogyakarta, 19 Juni 2010. ISSN : 1907-5022.

[6] Diyah Puspitaningrum., Dyan Kemala Sari., dan Boko Susilo., (2014). "Dampak Reduksi Sampel Menggunakan Principal Component Analysis (PCA) pada Pelatihan Jaringan Saraf Tiruan Terawasi (Studi Kasus : Pengenalan Angka Tulisan Tangan)”. Jurnal Pseudocode, Volume 2 Nomor 1, September 2014, ISSN 2355-5920.

[7] Elvia Budianita., dan Ulti Desi Arni., (2015). "Penerapan Learning Vector Quantization Penentuan Bidang Konsentrasi Tugas Akhir (Studi Kasus : Mahasiswa Teknik Informatika UIN Suska Riau)". Jurnal CorelT, Vol.1 (2), Desember 2015. ISSN : 2460738X (Cetak).

[8] Endi Permata., dan Andri Suherman., (2015). "Klasifikasi Kualitas Buah Garcia Mangostana L. Menggunakan Metode Learning Vector Quantization." Seminar Nasional Teknologi Informasi dan Komunikasi 2015 (SENTIKA 2015). Yogyakarta, 28 Maret 2015. ISSN : 2089-9815.

[9] Fachruddin Pakaja., Agus Naba., dan Purwanto (2012). "Peramalan Penjualan Mobil Menggunakan Jaringan Syaraf Tiruan dan Certaily Factor.” Jurnal EECCIS Vol. 6 (1), Juni 2012.

[10] Fajar Rohman Hariri,. Ema Utami., dan Armandyah Amborowati., (2015). "Learning Vector Quantization Untuk Klasifikasi Abstrak Tesis." Citec Journal, Vol. 2 (2). Februari 2015 - April 2015. ISSN : 2354-5771.

[11] J.K. Basu., D. Bhattacharyya., and Tai-hoon Kim., (2010). "Use of Artificial Neural Network in Pattern Recognition". International Journal of Software Enginerring and Its Applications Vol. 4 (20), April 2010.

[12] K. Prasad., D.C. Nigam., A. Lakhotiya., and D. Umre., (2013). "Character Recognition Using Matlab's Nueral Network Toolbox". International Journal of u- and e-Service, Science anda Technology Vol. 6 (1), Februari 2013.

[13] M. Arief Bustomi., Hasan Bisri., dan Endah Purwanti., (2014). "Desain Perangkat Lunak Jaringan Syaraf Tiruan Backpropagation untuk Klasisifikasi Citra Rontgen Paru-paru." Jurnal Fisika dan Aplikasinya. Vol. 10 (1). Januari 2014.

[14] Mohammad Valipour,. Mohammad Ebrahim Banihabib and Seyyed Mahmood Reza Behbahani., (2012)." Comparision of the ARMA, ARIMA, and the Autoregressive Artificial Neural Network Models in Forecasting the Monthly Inflow of Dez dam Reservoir." Journal of Hydrology 476 (2013) 433-441.

[15] Musli Yanto., Sarjon Defit., dan Gunadi Widi Nurcahyo., (2015). “Analisis Jaringan Syaraf Tiruan untuk Memprediksi Jumlah Reservasi Kamar Hotel dengan Metode Backpropagation (Studi Kasus : Hotel Grand Zuri Padang).” Jurnal KomTekInfo Fakultas Ilmu Komputer. Vol. 2 (1). Juni 2015. 